\title{
Intradialytic physical exercise in chronic kidney disease: a systematic review of health outcomes
}

\author{
Diego Fernández-Lázaro 1,2, Juan Mielgo-Ayuso³, María Paz Lázaro Asensio ${ }^{4,5}$, Alfredo Córdova Martínez³, \\ Alberto Caballero-García6, César I. Fernández-Lázaro',7
}

'Departamento de Biología Celular, Histología y Farmacología. Facultad de Ciencias de la Salud. Universidad de Valladolid. Campus de Soria. Soria. ${ }^{2}$ Grupo de Investigación de Neurobiología. Facultad de Medicina. Universidad de Valladolid. Valladolid. ㄹ. Departamento de Bioquímicay Fisiología. Facultad de Ciencias de la Salud. Universidad de Valladolid. Campus de Soria. Soria. ${ }^{4}$ Departamento de Fisioterapia. Facultad de Ciencias de la Salud. Universidad de Valladolid. Campus de Soria. Soria. ${ }^{5}$ Centro de Salud "La Milagrosa" Salud Castilla y León (SACyL). Soria. 'Departamento de Anatomía y Radiología. Facultad de Ciencias de la Salud. Universidad de Valladolid. Campus de Soria. Soria. 'Departamento de Medicina Preventiva y Salud Pública. Facultad de Medicina. Universidad de Navarra. Pamplona.

doi: 10.18176/archmeddeporte.00017

Received: $31 / 01 / 2020$ Accepted: 08/07/2020

Key words:

Chronic renal disease. Physical exercise. Hemodialysis. Physical capacity. Health-related quality of life. Biomarkers.

\section{Summary}

Introduction: Chronic kidney disease (CKD) is a general term for heterogeneous disorders that affect the structure and function of the kidney. Complications of CKD significantly limit exercise (Ex) tolerance by reducing functional capacity, endurance, and strength. However, the practice of regular Ex contributes to delaying the progression of CKD and stimulating improvements in health-related quality of life (HRQOL). Ex performed during the period of hemodialysis may be the best option when stimulating adherence and being under medical supervision. The purpose of the paper is to examine the effectiveness of intradialytic (iHD) Ex on health outcomes in patients with CKD by identifying the most appropriate component of Ex.

Material and method: Systematic review, based on PRISMA guidelines, performing a structured search in Medline, SciELO and Cochrane Library Plus databases. Publications from the last 5 years relating iHD Ex and CKD up to 31 December 2019 were included. The methodological quality of the articles was evaluated using the McMaster critical review form.

Results: We found 7 articles that described increases in endurance, upper and lower limb muscle strength, and HRQL of CKD patients providing emotional, social and psychological improvements. In addition, iHD Ex is able to control oxidative stress, inflammation, improve the lipid profile and stimulate endothelial progenitor cells, which together reduce the risk of mortality associated with multiple comorbidities in CKD patients, especially cardiovascular ones.

Conclusions: Ex provides improvements in physical function and capacity, HRQL and biological markers. Aerobic Ex, muscle strength Ex and combined Ex programs are used.

\section{Ejercicio físico intradialítico en la enfermedad renal crónica: Revisión sistemática sobre los resultados de salud}

\begin{abstract}
Resumen
Introducción: La enfermedad renal crónica (ERC) es un término general para los trastornos heterogéneos que afectan la estructura y la función del riñón. Las complicaciones de la ERC limitan considerablemente la tolerancia al ejercicio físico (EFi) al reducir la capacidad funcional, la resistencia y la fuerza. Sin embargo, la práctica de EFi regular contribuye a retrasar la progresión de la ERC y, estimular mejoras en la calidad de vida relacionada con la salud (CVRS). EFi realizado en período de hemodiálisis podría ser la mejor opción al estimular la adherencia y estar bajo la supervisión médica. El propósito del trabajo es examinar la efectividad de EFi intradialítico (iHD) sobre los resultados de salud en pacientes con ERC identificando el componente del EFi más adecuado.

Material y método: Revisión sistemática, basada en las guías PRISMA, realizando una búsqueda estructurada en las bases Medline, SciELO y Cochrane Library Plus. Se incluyeron publicaciones de los últimos 5 años que relacionaran el EFi iHD y la ERC hasta el 31 de diciembre de 2019. La calidad metodológica de los artículos se evaluó mediante el formulario de revisión crítica de McMaster.

Resultados: Se encontraron 7 artículos que han descrito incrementos de la resistencia aeróbica, la fuerza muscular de los miembros superiores e inferiores, y sobre la CVRS de los pacientes de ERC proporcionando mejoras emocionales, sociales y psicológicas. Además, el EFi iHD es capaz de controlar el estrés oxidativo, la inflamación, mejorar el perfil lipídico y estimular las células progenitoras endoteliales, lo que conjuntamente permite reducir los riegos de mortalidad asociada a las múltiples comorbilidades de los pacientes ERC, especialmente las cardiovasculares.

Conclusiones: EFi proporciona mejoras de la función y la capacidad física, la CVRS y los marcadores biológicos. Se emplean
\end{abstract} programas de EFi aeróbico, de fuerza muscular y EFi combinado de ambos. 


\section{Introduction}

Chronic kidney disease (CKD) is a general term covering heterogeneous disorders that affect the structure and function of the kidneys. CKD is classified according to the states of seriousness, which are assessed using the glomerular filtration rate (GFR), albuminuria, and clinical diagnosis (cause and pathology)'

In CKD, the increase of oxidative stress (OS), generalised inflammation, metabolic acidosis, uraemic syndrome, hormonal and haematological alterations, directly affect the cardiovascular system, the skeletal muscle, bone structure, the nervous system and haematopoiesis, considerably limiting tolerance to physical exercise (iPE) by reducing functional capacity, resistance, and strength ${ }^{2,3}$. For these reasons, CKD patients have been dissuaded from performing iPE as it could cause added deterioration to renal function resulting from a reduction of blood flow to the kidneys and increased proteinuria ${ }^{4}$. However, physical inactivity is the cause and effect of the progression of CKD because it directly contributes to the decrease in GFR5.

It has been reported that the regular practice of iPE establishes changes to the renal haemodynamic ${ }^{1}$ as a result of increased cardiac output, increased heart rate and greater venous return, which potentially contributes to slowing the progression of CKD' ${ }^{6}$. PPE for patients with $C K D$ subject to HD can be performed at two different times, interdialytic and intradialytic ( $\mathrm{iHD})^{7}$. $\mathrm{HHD}_{\mathrm{H}} \mathrm{PE}$ performed in the HD period is the best option for CKD patients undergoing HD, because extra time is not required as iPE and HD are performed simultaneously ${ }^{8}$. Furthermore, patients are under medical supervision, which means any complication can be detected and treated at the time ${ }^{9}$. iHD iPE can increase blood flow to the muscles, enabling the elimination of solutes and toxic agents with a better performance for dialysers ${ }^{10}$. iHD iPE also stimulates sweat and respiratory activity, increasing the elimination of excess body fluids and products deriving from the metabolism, allowing the re-establishment of the homeostasis acid-base ${ }^{9}$. This way, iPE during HD could reduce the physiological and psychological impact of treatment on patients, leading to better conditions during the wait for a future transplant ${ }^{11}$.. However, iPE is not free from complications in CKD patients undergoing $H D$, increasing the risk of suffering a fracture due to alterations of the bone metabolism, and mortality through cardiovascular accident ${ }^{12}$.

In Spain, there are currently no standardised and/or documented programmes for iHD iPE. Therefore, we intend to determine the potential effects of iHD iPE on health outcomes (linked to physical function, HRQOL and biological markers), aiming to identify the most suitable iPE component.

\section{Material and methods}

\section{Search strategy}

This study is a systematic review that focuses on the impact of performing $\mathrm{iHD}$ iPE on CKD patients. It was performed following specific
Table 1. Databases used and key words entered for each of the searches.

\begin{tabular}{c|l|l}
\hline Search number & Database & Search term \\
\hline 1 & $\begin{array}{l}\text { Medline (PubMed) } \\
\text { / Cochrane library } \\
\text { plus / SciELO }\end{array}$ & $\begin{array}{l}\text { Chronic kidney disease AND } \\
\text { hemodialysis AND physical } \\
\text { exercise }\end{array}$ \\
\hline 2 & $\begin{array}{l}\text { Medline (PubMed) } \\
\text { / Cochrane library } \\
\text { plus / SciELO }\end{array}$ & $\begin{array}{l}\text { Chronic kidney disease AND } \\
\text { hemodialysis AND physical } \\
\text { activity }\end{array}$ \\
\hline 3 & $\begin{array}{l}\text { Medline (PubMed) } \\
\text { Cochrane library } \\
\text { plus / SciELO }\end{array}$ & $\begin{array}{l}\text { Chronic kidney disease AND } \\
\text { hemodialysis AND physical } \\
\text { training }\end{array}$ \\
\hline
\end{tabular}

methodological guidelines, Preferred Reporting Items for Systematic Review and Meta-Analyses (PRISMA) ${ }^{13}$, and the PICOS question model to define the inclusion criteria: $\mathrm{D}$ (demographic): "patients with chronic kidney disease undergoing haemodialysis," ( intervention): "performing intradialytic physical exercise", C (comparison): "same conditions with/ without physical exercise", O (outcomes): "Physical, biological and quality of life modifications induced by undertaking physical exercise programmes", S (study design): "controlled design without placebo".

A search was carried out structured on the following electronic databases: Medline (PubMed), SciELO and Cochrane Library Plus. Publications from the previous 5 years were included, linking iHD iPE and CKD, to $31^{\text {st }}$ December 2019. The search criteria included a mixture of Medical Subject Headings (MeSH), and free text words for key concepts related to CKD and iPE (Table 1).

\section{Inclusion and exclusion criteria}

To select the studies, the following inclusion criteria were applied: i) Represent a well-designed experiment that included iPE in patients with CKR undergoing HD; ii) Performing iHD iPE; iii) An identical situation of patients with CKD without performing iPE; iv) Documents with a publication date within the past 5 years; v) Publications whose study subjects were humans aged over 18 years with CKD; vi) Languages were restricted to English, German, French, Italian, Spanish and Portuguese. The exclusion criteria applied were: i) Publications not related to CKD and iPE; ii) Duplicate documents, iii) Studies published more than 5 years ago; iv) Not performed on humans with CKD; v) No filter applied regarding previous level of physical condition, or capacity to perform physical activity; vi) The studies were narrative or systematic reviews; vii) Articles with poor methodological quality were excluded, $\leq 8$ points in accordance with the McMaster ${ }^{14}$ critical review formula for quantitative studies.

\section{Methodological quality assessment}

The methodological quality of the articles was assessed using the McMaster ${ }^{14}$ critical review formula. Points were obtained varying from 11 to 15 points, representing a minimum methodological quality of $68.8 \%$ and a maximum of $93.8 \%$. Of the 7 studies, 5 achieved "very good" 
Table 2. Methodological quality assessment.

\begin{tabular}{|c|c|c|c|c|c|c|c|c|c|c|c|c|c|c|c|c|c|c|c|}
\hline Reference & & & & & & & & tem & & & & & & & & & TS & $\%$ & MQ \\
\hline & 1 & 2 & 3 & 4 & 5 & 6 & 7 & 8 & 9 & 10 & 11 & 12 & 13 & 14 & 15 & 16 & & & \\
\hline Abreu et al..$^{20} 2017$ & 1 & 1 & 1 & 1 & 1 & 1 & 1 & 1 & 1 & 1 & 0 & 0 & 1 & 1 & 1 & 1 & 14 & 87.5 & VG \\
\hline Anding et al. ${ }^{6} 2015$ & 1 & 1 & 1 & 1 & 1 & 0 & 1 & 1 & 1 & 1 & 1 & 1 & 0 & 1 & 1 & 1 & 14 & 87.5 & VG \\
\hline Chan et al. ${ }^{15} 2016$ & 1 & 1 & 1 & 1 & 0 & 1 & 1 & 1 & 1 & 1 & 1 & 0 & 1 & 1 & 1 & 1 & 15 & 93.8 & E \\
\hline Cho et al..$^{16} 2018$ & 1 & 1 & 1 & 1 & 0 & 1 & 1 & 1 & 1 & 1 & 1 & 1 & 0 & 1 & 1 & 0 & 13 & 81.3 & VG \\
\hline Groussard et al. ${ }^{17} 2015$ & 1 & 1 & 1 & 1 & 1 & 0 & 1 & 1 & 1 & 1 & 1 & 1 & 0 & 1 & 1 & 1 & 14 & 87.5 & VG \\
\hline Liao et al. ${ }^{18} 2016$ & 1 & 1 & 1 & 1 & 1 & 0 & 1 & 1 & 1 & 1 & 1 & 1 & 0 & 1 & 1 & 1 & 14 & 87.5 & VG \\
\hline Wu et al. ${ }^{19} 2014$ & 1 & 1 & 1 & 1 & 1 & 0 & 1 & 1 & 1 & 1 & 0 & 0 & 0 & 1 & 0 & 1 & 11 & 68.8 & G \\
\hline $\mathrm{T}$ & 7 & 7 & 7 & 10 & 5 & 7 & 7 & 7 & 7 & 7 & 5 & 4 & 2 & 7 & 6 & 6 & & & \\
\hline
\end{tabular}

T: total items completed; TS: total items completed by study.

1: Criteria fulfilled; 0 : Criteria not fulfilled.

MQ: Methodological quality (poor $\leq 8$ points; acceptable 9-10 points; good 11-12 points; very good $13-14$ points; excellent $\geq 15$ ).

Table 3. Articles found in the different databases.

\begin{tabular}{|c|c|c|c|c|}
\hline Search term & $\begin{array}{l}\text { No. articles after } \\
\text { applying filters }\end{array}$ & $\begin{array}{l}\text { No. articles after } \\
\text { reading title }\end{array}$ & $\begin{array}{l}\text { No. articles after } \\
\text { reading abstract }\end{array}$ & $\begin{array}{l}\text { Articles } \\
\text { selected }\end{array}$ \\
\hline Chronickidneydisease AND hemodialysis AND physicalexercise & 61 & 8 & 5 & 4 \\
\hline Chronickidneydisease AND hemodialysis AND physicalactivity & 66 & 5 & 4 & 2 \\
\hline Chronickidneydisease AND hemodialysis AND physical training & 41 & 2 & 1 & 1 \\
\hline
\end{tabular}

Figure 1. Study selection.

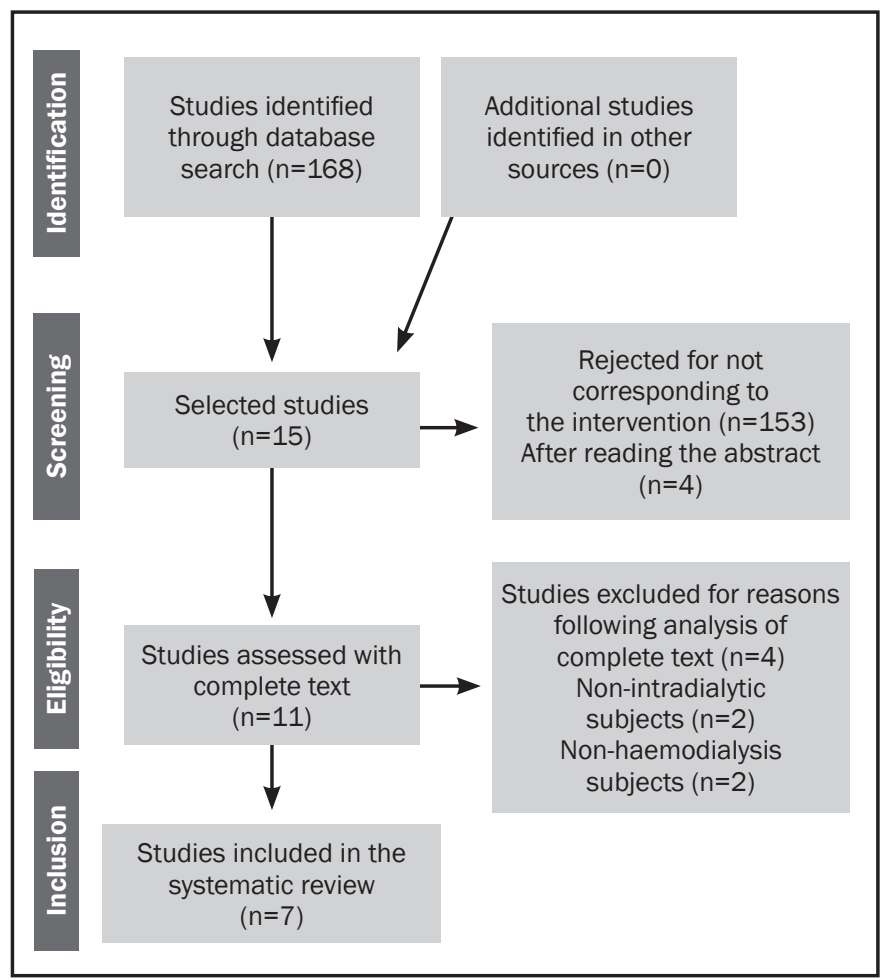

quality, 1 "good", and 1 study achieved "excellent" (Table 2). None of the studies were excluded for not reaching the minimum quality threshold.

\section{Results}

\section{Study selection}

The search threw up 168 articles, after applying the corresponding filters (Table 3). After reading the title and the summary, 15 articles were chosen, of which 2 were excluded as they were studies without intervention, and 2 for not fulfilling the corresponding data. The complete texts of the 11 remaining publications were assessed in adherence to the inclusion criteria, based on which 2 studies were eliminated for not performing iHD iPE and 2 for performing another type of dialysis. This way, 7 articles were obtained for inclusion in this systematic review (Figure 1).

\section{Results measured}

Table 4 includes information about the study source data (including authors and year of publication), study type, dialysis, stage of the CKD, type and performance protocol of the iHD iPE. Tables 5a, 5b and $5 c$ display information about the assessment tests, results and conclusions of the health markers analysed in CKD patients in HD.

\section{Discussion}

The studies included in this work are controlled trials that are considered suitable for examining whether there is a cause-effect relationship between performing iPE and possible benefits on CKD patients during HD. The most relevant results of this systematic review reveal that iPE 
programmes significantly improve aerobic resistance, strength and physical function ${ }^{6,15-19}$. Furthermore, these programmes improve HRQOL significantly in the physical, social and psychological sub-scales, 5, 15,16,19,20 and even in quality of sleep (QS) ${ }^{16}$. iPE also had a positive influence on some biological markers linked to: OS, inflammatory status, lipid profile, blood pressure and endothelial regenerative capacity ${ }^{17,18,20}$. To provide

Table 4. Summary of the general study characteristics included in the review that research the impact of physical exercise on patients with chronic kidney disease in haemodialysis.

\begin{tabular}{|c|c|c|c|c|c|c|}
\hline Author & Demographic & Study type & Dialysis & $\begin{array}{l}\text { Chronic } \\
\text { kidney disea- } \\
\text { se study }\end{array}$ & $\begin{array}{c}\text { Type of intradialytic } \\
\text { exercise }\end{array}$ & Performance protocol \\
\hline $\begin{array}{l}\text { Abreu et al. } .^{20} \\
2017\end{array}$ & $\begin{array}{l}n=44>18 \text { years } \\
\text { CG: } n=19(61.5 \% \text {, aged } \\
42.5 \pm 13.5 \text { years and time } \\
\text { of dialysis }=70.1 \pm 49.9 \\
\text { months). } \\
\text { iPEG: } n=25(54.5 \% \text {, aged } \\
45.7 \pm 15.2 \text { years and time } \\
\text { of dialysis }=71.2 \pm 45.5 \\
\text { months) } \\
\text { iPEG adherence } 78.1 \%\end{array}$ & $\begin{array}{l}\text { Randomised } \\
\text { control } \\
\text { Patients with } \\
\text { co-morbidities } \\
\text { that impeded the } \\
\text { practice of iPE } \\
\text { were excluded }\end{array}$ & $\begin{array}{l}3 \text { sessions* } \\
\text { week. } \\
3-4 \text { hours } \\
\text { Blood } \\
\text { flow: } 250 \mathrm{~mL} / \\
\text { min and } \\
\text { dialysed } 500 \\
\mathrm{~mL} / \mathrm{min}\end{array}$ & $\begin{array}{l}\text { Stage IV } \\
\text { Maintenance } \\
\text { dialysis }>6 \\
\text { months }\end{array}$ & $\begin{array}{l}\text { Strength } \\
\text { Exercise LL } \\
3 \text { months, } 3 \text { times/ } \\
\text { week } \\
\text { ( } 36 \text { sessions), } 30 \\
\text { minutes in the } 2 \text { nd } \\
\text { half hour of dialysis }\end{array}$ & $\begin{array}{l}3 * 10 \text { repetitions in } 4 \text { different } \\
\text { exercises with anklets and } \\
\text { elastic bands (Theraband }{ }^{\oplus} \text { ) } \\
\text { on LL. } \\
\text { Load: } \\
\text { Theraband: } 1.6 / 10 \mathrm{~kg} \\
\text { Mvts ankle: } 1 / 12 \mathrm{~kg} \\
\text { Intensity: } 60 \% \text { of } 1 \mathrm{RM}\end{array}$ \\
\hline $\begin{array}{l}\text { Anding et al. }{ }^{6} \\
2015\end{array}$ & $\begin{array}{l}\mathrm{n}=46 \\
22 \text { \% and } 24 \% \\
63.2 \pm 16.3 \text { years } \\
3 \text { groups depending on } \\
\text { adherence to the iPE } \\
\text { sessions } \\
\text { High } \mathrm{HA}>80 \% \\
\text { Medium MA } 60-80 \% \\
\text { Low LA }<60 \% \\
\text { iPEG adherence } 78.1 \%\end{array}$ & $\begin{array}{l}\text { Controlled - Non } \\
\text { randomised } \\
\text { monocentric } \\
\text { Patients with } \\
\text { co-morbidities } \\
\text { that impeded the } \\
\text { practice of iPE } \\
\text { were excluded }\end{array}$ & $\begin{array}{l}4-5 \text { hours } \\
3 \text { times/week. }\end{array}$ & $\begin{array}{l}\text { Stage IV. } \\
\text { Maintenance } \\
\text { dialysis }>3 \\
\text { months }\end{array}$ & $\begin{array}{l}\text { Strength UL/LL and } \\
\text { resistance } 30 \text { minutes } \\
{ }^{*} \text { session and } 2^{*} \text { week } \\
=60 \text { minutes week } \\
\text { during the first } 2 \\
\text { hours of dialysis } \\
1 \text { year ( } 104 \text { sessions). }\end{array}$ & $\begin{array}{l}\text { Strength: } 8 \text { muscle groups. } \\
2^{*} \text { series of } 1 \text { minute and } 1 \\
\text { minute rest. Customised load } \\
\text { calculated by the repetition } \\
\text { rate (R) } \\
\text { UL weights of } 0.5-4 \mathrm{~kg} \\
\text { LL elastic bands of different } \\
\text { resistances. } \\
\text { Resistance: stationary cycling } \\
\text { on supine cycloergometer } \\
\text { (MOTOmed2) work on } \\
\text { customised pulsations } \\
\text { calculated using the Karvonen } \\
\text { method. }\end{array}$ \\
\hline $\begin{array}{l}\text { Chan et al. } .^{15} \\
2016\end{array}$ & $\begin{array}{l}n=22>40 \text { years } \\
\left(59 \% \sigma^{\star}, 71 \pm 11 \text { years) }\right. \\
\text { iPE adherence } 71.2 \% \pm \\
23.3 \%\end{array}$ & $\begin{array}{l}\text { Controlled crosso- } \\
\text { ver non randomi- } \\
\text { sed trial } \\
\text { Patients with } \\
\text { co-morbidities } \\
\text { that impeded the } \\
\text { practice of iPE } \\
\text { were excluded }\end{array}$ & $\begin{array}{l}3 \text { hours } \\
3 \text { times/week. }\end{array}$ & $\begin{array}{l}\text { Stage IV. } \\
\text { Maintenance } \\
\text { dialysis }>3 \\
\text { months }\end{array}$ & $\begin{array}{l}\text { iHD progressive } \\
\text { strength training } \\
3 \text { times/week. } 30 \\
\text { minutes during the } \\
1 \text { st half of HD. } \\
12 \text { weeks } \\
36 \text { sessions }\end{array}$ & $\begin{array}{l}2 \text { * Strength exercises on UL } \\
\text { biceps, deltoids and triceps. } \\
\text { Pre-dialysis vascular access } \\
\text { arm, intradialysis non-vascular } \\
\text { access arm } \\
3 \text { * Strength exercises on LL } \\
\text { quadriceps and hamstrings } \\
\text { Load: between } 2.5-59 \mathrm{~kg} \\
\text { Mode: Unilateral and bilateral }\end{array}$ \\
\hline $\begin{array}{l}\text { Cho et al. }{ }^{16} \\
2018\end{array}$ & $\begin{array}{l}\mathrm{n}=57260^{x} \text { and } 31 \text { \% } \\
\text { Not hospitalised in the } \\
\text { past } 3 \text { months. } \\
4 \text { groups: } \\
\text { CG control } n=13 \\
\text { AW aerobic } i P E n=15 \\
\text { RE iPE strength } n=14 \\
\text { CE iPE } n=15 \text { aerobic + } \\
\text { strength } \\
\text { iPE adherence } 81 \%\end{array}$ & $\begin{array}{l}\text { Randomised } \\
\text { control } \\
\text { Patients with } \\
\text { co-morbidities } \\
\text { that impeded the } \\
\text { practice of iPE } \\
\text { were excluded }\end{array}$ & $\begin{array}{l}3 \text { times/ } \\
\text { week }\end{array}$ & $\begin{array}{l}\text { Stage IV. } \\
\text { Maintenance } \\
\text { haemodialysis } \\
\geq 6 \text { months }\end{array}$ & $\begin{array}{l}-\mathrm{AW} \\
-\mathrm{RE} \\
-\mathrm{CE} \\
5 \text { min warm-up }+ \\
30 \text { min main part }+ \\
5 \text {-minute cool-down } \\
\text { Performed in the first } \\
2 \text { hours of dialysis. } \\
12 \text { weeks } 3 \text { times/ } \\
\text { week. } \\
36 \text { sessions }\end{array}$ & $\begin{array}{l}\text { AW: stationary cycling on } \\
\text { supine cycloergometer } \\
\text { (SP2100R) with an intensity of } \\
60-70 \% \text { of maximum capacity. } \\
11-13 \text { Borg Scale } 15 \text { points. } \\
\text { RE: supine or seated position } \\
\text { with elastic resistance bands } \\
\text { (Theraband }{ }^{\oplus} \text { ) and soft weights } \\
\text { on LL (quadriceps, vastus } \\
\text { lateralis, adductor and femoral } \\
\text { biceps) and UL (biceps brachii, } \\
\text { triceps and deltoids) } 3 \text { series * } \\
10-15 \text { repetitions. } \\
\text { Pre-dialysis vascular access } \\
\text { arm, intradialysis non-vascular } \\
\text { access arm } \\
\text { CE: AW + RE }\end{array}$ \\
\hline
\end{tabular}




\begin{tabular}{|c|c|c|c|c|c|c|}
\hline Author & Demographic & Study type & Dialysis & $\begin{array}{c}\text { Chronic } \\
\text { kidney disease } \\
\text { study }\end{array}$ & $\begin{array}{c}\text { Type of intradialytic } \\
\text { exercise }\end{array}$ & Performance protocol \\
\hline $\begin{array}{l}\text { Groussard et } \\
\text { al. }{ }^{17} 2015\end{array}$ & $\begin{array}{l}n=20150^{\pi} \text { and } 5 \text { क } \\
\text { Age } 20-85 \text { years } \\
\text { CG } n=10 \\
\text { iPEG } n=10 \\
\text { iPE adherence } 80 \%\end{array}$ & $\begin{array}{l}\text { Randomised } \\
\text { control } \\
\text { Patients with } \\
\text { co-morbidities } \\
\text { that impeded the } \\
\text { practice of iPE } \\
\text { were excluded }\end{array}$ & 3 times/week & $\begin{array}{l}\text { Stage IV. } \\
\text { Maintenance } \\
\text { haemodialysis } \\
>2 \text { years }\end{array}$ & $\begin{array}{l}\text { AW } \\
3 \text { days/week. } \\
5 \text { min warm-up }+30 \\
\text { min main part }+5 \\
\text { min cool-down } \\
\text { Performed in the first } \\
2 \text { hours of dialysis. } \\
3 \text { months ( } 12 \text { weeks) } \\
3 \text { times/week. } \\
36 \text { sessions }\end{array}$ & $\begin{array}{l}\text { AW: stationary cycling on supi- } \\
\text { ne cycloergometer (Oxycycle) } \\
\text { with an intensity of } 55-60 \% \\
\text { of maximum capacity and } \\
\text { frequency of } 50 \text { rpm. }\end{array}$ \\
\hline $\begin{array}{l}\text { Liao et al. }{ }^{18} \\
2016\end{array}$ & $\begin{array}{l}n=4023 \text { and } 170^{\pi} \\
\text { Age } 62 \pm 8 \text { years } \\
\text { CG } n=20 \\
\text { iPEG } n=20 \\
\text { iPE adherence not } \\
\text { specified }\end{array}$ & $\begin{array}{l}\text { Randomised } \\
\text { control } \\
\text { Patients with } \\
\text { co-morbidities } \\
\text { that impeded the } \\
\text { practice of iPE } \\
\text { were excluded }\end{array}$ & $\begin{array}{l}3 \text { times/ } \\
\text { week } \\
4 \text { hours/ } \\
\text { Session }\end{array}$ & $\begin{array}{l}\text { Stage IV. } \\
\text { Maintenance } \\
\text { haemodialysis } \\
>6 \text { months }\end{array}$ & $\begin{array}{l}\text { AW } \\
3 \text { days/week. } \\
5 \text { min warm-up }+ \\
20 \text { min main part } \\
+5 \text { min cool-down } \\
\text { Performed in the first } \\
2 \text { hours of dialysis. } 3 \\
\text { months (12 weeks) } \\
3 \text { times/week. } 36 \\
\text { sessions }\end{array}$ & $\begin{array}{l}\text { AW: stationary cycling on a } \\
\text { supine cycloergometer. With } \\
\text { an intensity of } 12-15 \text { on the } \\
\text { Borg Scale }\end{array}$ \\
\hline $\begin{array}{l}\text { Wu et al. }{ }^{19} \\
2014\end{array}$ & $\begin{array}{l}n=6555 \sigma^{x} \text { and } 10 \% \\
C G n=3344(41-50) \text { years } \\
\text { iPEG } n=3245(37-48) \\
\text { years } \\
\text { iPE adherence } 84 \%\end{array}$ & $\begin{array}{l}\text { Randomised } \\
\text { control } \\
\text { Patients with } \\
\text { co-morbidities } \\
\text { that impeded the } \\
\text { practice of iPE } \\
\text { were excluded }\end{array}$ & $\begin{array}{l}3 \text { times/ } \\
\text { week } \\
4 \text { hours/ } \\
\text { Session } \\
\text { Blood } \\
\text { flow: } 250 \mathrm{~mL} / \\
\text { min and dialy- } \\
\text { sed } 500 \mathrm{~mL} / \\
\text { min }\end{array}$ & $\begin{array}{l}\text { Stage IV. } \\
\text { Maintenance } \\
\text { dialysis }>3 \\
\text { months. }\end{array}$ & $\begin{array}{l}\text { AW } \\
5 \text { min warm-up 10-15 } \\
\text { min main part } \\
\text { during HD } 3 \text { times/ } \\
\text { week. } 12 \text { weeks } 36 \\
\text { sessions }\end{array}$ & $\begin{array}{l}\text { AW: Stationary cycling on a } \\
\text { supine cycloergometer with an } \\
\text { intensity of } 12-16 \text { on the Borg } \\
\text { scale associated to energy } \\
\text { between } 70-100 \mathrm{kcal} \text { and an } \\
\text { increased heart rate of } 20 \\
\text { beats } / \mathrm{min} \text {. }\end{array}$ \\
\hline
\end{tabular}

CG: control group; iPEG: physical exercise group; iPE: physical exercise; ㅇ female; ơ: male; iHD: intradialytic; HA: high adherence; MA: medium adherence; LA: low adherence; AW: aerobic; RE: strength CE: aerobic + strength; mL: millilitres; min: minutes; * multiplication symbol

a clearer analysis, the variables included in this systematic review were grouped as follows.

\section{Intradialytic physical exercise}

Before applying an iHD iPE programme, it is vital to establish the time of performance, duration, intensity and iPE modality. In this respect, iHD iPE was performed in the first half15 or within the first two hours ${ }^{6,16-18,20}$ of the HD, mainly due to the hypothetical risks of iPE, given that it could exacerbate haemodynamic instability and/or the appearance of muscle cramps during the final stages of an HD session?. iPE usually triggers an increase in blood pressure, as well as posterior hypotension, which is the greatest concern, as presumably this could increase the risk of adverse ischaemic episodes, in particular during the final stage of CKD when the total volume of blood is reduced by ultrafiltration with the iHD iPE ${ }^{21,22}$. Only Chan et al..$^{15}$ reported a single adverse effect on one patient, with dizziness associated to hypotension in 1 of the 401 sessions carried out, entailing a risk of $0.25 \%$. Liao et al. ${ }^{18}$ reported modulations in systolic, diastolic blood pressure and in heart rate after 3 months of
iHD aerobic cycling training, during the prior basal period iPE ${ }^{18}$, which could reduce the symptoms associated with hypotension from the HD. At the time the iPE of the studies analysed was performed, it was probably based on a study carried out by Moore et al. ${ }^{23}$, which revealed that moderate intensity iPE was well tolerated during the first and second hour of treatment, but not during the third hour due to the hypotension associated with the drop in blood pressure, systolic volume and cardiac output. Conversely, a recent study by Jeong et al. ${ }^{24}$ found no differences in the iHD haemodynamic parameters between the first or third hour of $H D$, which would indicate the safety of $\mathrm{HHD}$ iPE even when performed during the last hours of HD. Therefore, the patient could be given the opportunity to choose the time to perform iPE, stimulating adherence to the iPE programme.

The deteriorated state of health of patients with CKD undergoing HD does not allow for iPE programmes with overly long sessions, therefore 30 minutes has been established as the most appropriate length for the main part of the session ${ }^{6,15-17,20}$, though Liau et al. ${ }^{18}$ and Wu et al. ${ }^{19}$ performed shorter sessions. Some studies also included a previous 
Table 5a. Summary of the assessment tests, results and conclusions of the physical function and capacity markers of the studies included in the review that research the impact of physical exercise on patients with chronic kidney disease in haemodialysis.

\begin{tabular}{|c|c|c|c|c|}
\hline Author & Demographic & Assessment & Results & Conclusions \\
\hline $\begin{array}{l}\text { Anding et al. }{ }^{6} \\
2015\end{array}$ & $\begin{array}{l}\mathrm{n}=46 \\
22 \% \text { and } 24 \sigma^{x} \\
63.2 \pm 16.3 \text { years } \\
3 \text { groups depending on } \\
\text { adherence to the iPE sessions } \\
\text { High } \mathrm{HA}>80 \% \\
\text { Medium MA } 60-80 \% \\
\text { Low LA }<60 \% \\
\text { Average iPEG adherence } 78.1 \%\end{array}$ & $\begin{array}{l}\text { Strength: } 8 \text { muscle groups } \\
\text { Maximum strength tests } \\
\text { (maximum no. of exercise } \\
\text { repetitions). } \\
\text { Resistance: average power (w) } \\
\text { Physical function: } \\
-6 \text { min walking test } \\
\text { - timed up and go test } \\
\text { - sit to stand test (STS60) }\end{array}$ & $\begin{array}{l}\text { Strength } \uparrow^{*} \mathrm{HA}(120 \%) \text { and } \\
\text { MA (40-50\%) LL: extension } \\
\text { of leg, adductor, abductor } \\
\text { and abdomen. UL: biceps } \\
\text { and triceps. } \\
\text { Resistance: } \uparrow^{*} \mathrm{HA}(55 \%) \text { and } \\
\text { MA (45\%) } \\
\text { Physical function } \uparrow^{*} 11-31 \% \\
\mathrm{n}=46 \\
\cdot 6 \text { min walking test } \uparrow . \\
\text { timed up and go test } \uparrow^{*} \\
\text {-sit to stand test (STS60) } \uparrow^{*}\end{array}$ & $\begin{array}{l}\text { The iPE strength and resistance } \\
\text { programme significantly improved } \\
\text { resistance, strength and physical } \\
\text { function. Furthermore, it can be } \\
\text { integrated into a routine for patients } \\
\text { with CKD in HD with high adherence. }\end{array}$ \\
\hline $\begin{array}{l}\text { Chan et al. } .^{15} \\
2016\end{array}$ & $\begin{array}{l}\mathrm{n}=22>40 \text { years } \\
\left(59 \% \sigma^{\pi}, 71 \pm 11 \text { years }\right) \\
\text { iPE adherence } 71.2 \% \pm 23.3 \%\end{array}$ & $\begin{array}{l}\text { Strength (balance machine) on } \\
\mathrm{UL} \text { and LL } \\
\text { Aerobic } 6 \text { min walking test }\end{array}$ & $\begin{array}{l}\text { Strength } \uparrow * \text { LL } \uparrow U L \\
6 \text { min walking test } \uparrow\end{array}$ & $\begin{array}{l}\text { Progressive iHD resistance training } \\
\text { significantly improved physical } \\
\text { health measurements, significantly } \\
\text { increasing strength in the LL and UL. } \\
\text { Improvements were also observed in } \\
\text { the AW component. }\end{array}$ \\
\hline $\begin{array}{l}\text { Cho et al. }{ }^{16} \\
2018\end{array}$ & $\begin{array}{l}n=57260^{\pi} \text { and } 31 \text { \% } \\
\text { Not hospitalised in the past } 3 \\
\text { months. } \\
4 \text { groups: } \\
\text { CG control } n=13 \\
\text { AW aerobic iPE } n=15 \\
\text { RE iPE strength } n=14 \\
\text { CE iPE } n=15 \text { aerobic + strength } \\
\text { iPE adherence } 81 \%\end{array}$ & $\begin{array}{l}\text { DPA } \\
\text { EMR } \\
\text { No. AE*week } \\
\text { TAE*day (minutes) } \\
\text { No. SE*week } \\
\text { MSE*day (minutes) } \\
\% \text { MVPA } \\
\text { PAEE (kcal/day) }\end{array}$ & $\begin{array}{l}\mathrm{DPA} \\
\mathrm{EMR} \uparrow * \mathrm{AW} \text { and } \mathrm{CE} / \uparrow^{*} \mathrm{CE} \\
\text { vs. CG } \\
\text { No. AE } \uparrow * \mathrm{CE} \\
\mathrm{TAET} \approx \\
\mathrm{N} \cdot \mathrm{SE} \downarrow^{*} \mathrm{AW}, \mathrm{RE} \text { and CE } \\
\mathrm{MSE} \downarrow^{*} \mathrm{AW}, \mathrm{RE} \text { and CE } \\
\mathrm{MVPA} \uparrow * \mathrm{CE} \\
\mathrm{PAEE} \approx\end{array}$ & $\begin{array}{l}\text { iHD iPE, particularly } C E \text {, is clinically } \\
\text { beneficial to improving DPA and } \\
\text { reducing sedentary behaviour in } \\
\text { patients with CKD in HD. }\end{array}$ \\
\hline $\begin{array}{l}\text { Groussard et } \\
\text { al. }{ }^{17} 2015\end{array}$ & $\begin{array}{l}\mathrm{n}=2015 \sigma^{\pi} \text { and } 5 \text { क } \\
\text { Age } 20-85 \text { years } \\
\text { CG } \mathrm{n}=10 \\
\text { iPEG } \mathrm{n}=10 \\
\text { iPE adherence } 80 \%\end{array}$ & $\begin{array}{l}\mathrm{VO}_{2} \text { peak } \\
\text { Peak Power } \\
6 \text { min walking test }\end{array}$ & $\begin{array}{l}\mathrm{VO}_{2} \text { peak } \approx \mathrm{GC} \text { y GEFi } \\
\text { Peak Power } \approx \mathrm{GC} \text { y GEFi } \\
6 \text { min walking test } \uparrow^{*} \mathrm{GEFi} \\
\approx \mathrm{GC}\end{array}$ & $\begin{array}{l}\text { An iHD AW programme is beneficial } \\
\text { to physical aptitude by increasing the } \\
\text { distance covered during the } 6 \text { min } \\
\text { walking test, considering the relatively } \\
\text { short duration of only } 3 \text { months with } \\
36 \text { sessions. }\end{array}$ \\
\hline $\begin{array}{l}\text { Liao et al. }{ }^{18} \\
2016\end{array}$ & $\begin{array}{l}\mathrm{n}=4023 \% \text { and } 170^{\pi} \\
\text { Edad } 62 \pm 8 \text { años } \\
\mathrm{GC} n=20 \\
\text { GEFi } n=20 \\
\text { iPE adherence not specified }\end{array}$ & 6 min walking test & 6 min walking test $\uparrow *$ GEFi & $\begin{array}{l}\text { iHD AW iPE cycling at a moderate } \\
\text { intensity improves the aerobic physical } \\
\text { condition of CKD patients in HD. }\end{array}$ \\
\hline $\begin{array}{l}\text { Wu et al. }{ }^{19} \\
2014\end{array}$ & $\begin{array}{l}n=6555 \sigma^{7} \text { and } 10 \% \\
\text { CG } n=3344(41-50) \text { years } \\
\text { iPEG } n=3245(37-48) \text { years } \\
\text { iPE adherence } 84 \%\end{array}$ & $\begin{array}{l}\text { Physical Condition } \\
6 \text { min walking test } \\
\text { time taken to walk up and } \\
\text { down } \\
22 \text { steps } \\
\text { sit-to-stand test } \\
\text { grip strength test }\end{array}$ & $\begin{array}{l}\text { Physical Condition } \neq^{*} \text { iPEG } \\
\text { vs CG } \\
6 \text { min walking test } \uparrow * \text { iPEG } \\
\text { time taken to walk up down } \\
\text { and } 22 \text { steps } \uparrow * \text { iPEG } \\
\text { sit-to-stand test } \uparrow *_{i} \text { PEG } \\
\text { grip strength test } \uparrow *_{i} \text { PEG }\end{array}$ & $\begin{array}{l}\text { Customised iHD iPE significantly } \\
\text { improved the physical capacity of CKD } \\
\text { patients in a short period of time, and } \\
\text { therefore could be used as a simple } \\
\text { therapeutic focus with no adverse } \\
\text { effects }\end{array}$ \\
\hline
\end{tabular}

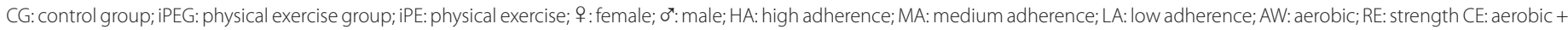

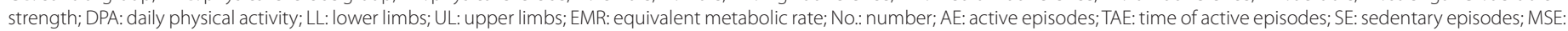

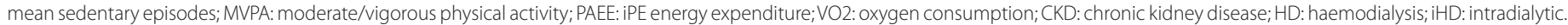

5-minute warm-up ${ }^{16-19}$, and further 5 minutes of cool-down after the main part of the iPE ${ }^{16-18}$.

Customising the intensities is considered essential, not only to adapt to physical capacities, but also to align with the CKD evolution of each patient and for other factors associated with the clinical process of HD5. Both aerobic work (AW) and strength work (St) were performed at moderate intensity between $55-70 \%$ of the maximum of each patient ${ }^{16,17,20}$, and/or an intensity ranging from 11 to 16 points on Borg's perceived 
Table 5b. Summary of the assessment, results and conclusions of the quality-of-life markers of the studies included in the review that research the impact of physical exercise on patients with chronic kidney disease in haemodialysis.

\begin{tabular}{|c|c|c|c|c|}
\hline Author & Demographic & Assessment & Results & Conclusions \\
\hline $\begin{array}{l}\text { Abreu et al. } .^{20} \\
2017\end{array}$ & $\begin{array}{l}\mathrm{n}=44>18 \text { years } \\
\text { CG: } \mathrm{n}=19(61.5 \% \text { \% , aged } \\
42.5 \pm 13.5 \text { years and time of } \\
\text { dialysis }=70.1 \pm 49.9 \text { months). } \\
\text { iPEG: } \mathrm{n}=25(54.5 \% \text { of } 45.7 \pm 15.2 \\
\text { years and time of } \\
\text { dialysis }=71.2 \pm 45.5 \text { months }) \\
\text { iPEG adherence } 78.1 \%\end{array}$ & $\begin{array}{l}\text { QoL test SF-36 } \\
\text { Physical function } \\
\text { Physical limitations role } \\
\text { Body pain } \\
\text { Vitality } \\
\text { General health } \\
\text { Mental health } \\
\text { Mental limitations role } \\
\text { Social function }\end{array}$ & $\begin{array}{l}\text { QoL } \neq^{*} \text { iPEG vs CG } \\
\text { Physical function } \approx \\
\text { Physical role } \uparrow^{*} \\
\text { Body pain } \approx \\
\text { Vitality } \approx \\
\text { General health } \uparrow^{*} \\
\text { Mental health } \uparrow^{*} \\
\text { Mental Role } \approx \\
\text { Social function } \approx\end{array}$ & $\begin{array}{l}\text { iPE strength in LL } \\
\text { for } 3 \text { months contributed to the } \\
\text { improvement of QoL in patients } \\
\text { with CKD in HD }\end{array}$ \\
\hline $\begin{array}{l}\text { Anding et al. }{ }^{6} \\
2015\end{array}$ & $\begin{array}{l}\mathrm{n}=46 \\
22 \text { \% and } 24 \sigma^{\pi} \\
63.2 \pm 16.3 \text { years } \\
3 \text { groups depending on adheren- } \\
\text { ce to the iPE sessions } \\
\text { High } \mathrm{HA}>80 \% \\
\text { Medium MA } 60-80 \% \\
\text { Low LA }<60 \% \\
\text { Average iPEG adherence } 78.1 \%\end{array}$ & $\begin{array}{l}\text { QoL test SF-36 } \\
\text { Physical function } \\
\text { Physical limitations role } \\
\text { Body pain } \\
\text { Vitality } \\
\text { General health } \\
\text { Mental health } \\
\text { Mental limitations role } \\
\text { Social function }\end{array}$ & $\begin{array}{l}\uparrow \text { iPEG QoL SF36 } \\
\text { Physical function } \uparrow * \\
\text { Physical limitations role } \uparrow * \\
\text { Body pain } \approx \\
\text { Vitality } \approx \\
\text { General health } \approx \\
\text { Mental health } \approx \\
\text { Mental limitations role } \uparrow * \\
\text { Social function } \approx\end{array}$ & $\begin{array}{l}\text { Improvement of QoL in iPEG } \\
\text { assessed using the SF- } 36 \text { test and } \\
\text { significant improvement in the } \\
\text { sub-scales of physical function, } \\
\text { function of physical/emotional } \\
\text { limitations. }\end{array}$ \\
\hline $\begin{array}{l}\text { Chan et al. }{ }^{15} \\
2016\end{array}$ & $\begin{array}{l}\mathrm{n}=22>40 \text { years } \\
(59 \% \bigotimes, 71 \pm 11 \text { years }) \\
\text { iPE adherence } 71.2 \% \pm 23.3 \%\end{array}$ & $\begin{array}{l}\text { QoL test SF-36 } \\
\text { Adverse effects (structured } \\
\text { medical questionnaire) }\end{array}$ & $\begin{array}{l}\uparrow \text { QoL SF-36 } \\
-\uparrow * 3 \text { sub-scales: } \\
\text { physical, social and emotional } \\
-\downarrow 1 \text { sub-scale: depression } \\
\\
\text { Of } 401 \text { total sessions }(n=22) 1 \\
\text { patient suffered dizziness: Risk } \\
0.25 \% \text { equivalent to } 1 / 401\end{array}$ & $\begin{array}{l}\text { Progressive iHD resistance } \\
\text { training improved QoL. } \\
\text { Furthermore, it can be } \\
\text { worked into a routine for patients } \\
\text { with CKD in HD with a high } \\
\text { adherence and with no adverse } \\
\text { effects }\end{array}$ \\
\hline $\begin{array}{l}\text { Cho et al. }{ }^{16} \\
2018\end{array}$ & $\begin{array}{l}n=57260^{\pi} \text { and } 31 \text { \% } \\
\text { Not hospitalised in the past } 3 \\
\text { months. } \\
4 \text { groups: } \\
\text { CG control } n=13 \\
\text { AW aerobic iPE } n=15 \\
\text { RE iPE strength } n=14 \\
\text { CE iPE } n=15 \text { aerobic + strength } \\
\text { iPE adherence } 81 \%\end{array}$ & $\begin{array}{l}\text { QS } \\
\% \mathrm{MI} \\
\% \mathrm{FI} \\
\% \mathrm{SFI}=\mathrm{MI}+\mathrm{FI} \\
\text { TST } \\
\text { WASO } \\
\% \mathrm{SE}\end{array}$ & $\begin{array}{l}\text { QS } \\
\% \mathrm{MI} \downarrow * \mathrm{AW}, \mathrm{RE} \text { and CE } \\
\% \mathrm{FI} \quad \downarrow * \mathrm{CG} \\
\mathrm{SFI} \downarrow \mathrm{AW} \text { and } \mathrm{RE} \\
\mathrm{TST} \approx \\
\mathrm{WASO} \approx \\
\% \mathrm{SE} \approx\end{array}$ & $\begin{array}{l}\text { iHD iPE, particularly } C E \text {, is } \\
\text { clinically beneficial to improving } \\
\text { SQ in patients with CKD in HD. }\end{array}$ \\
\hline $\begin{array}{l}\text { Wu et al. }{ }^{19} \\
2014\end{array}$ & $\begin{array}{l}n=6555 \sigma^{\pi} \text { and } 10 \% \\
\text { CG } n=3344(41-50) \text { years } \\
\text { iPEG } n=3245(37-48) \text { years } \\
\text { iPE adherence } 84 \%\end{array}$ & $\begin{array}{l}\text { QoL } \\
\text { KDQOL-SFTM } \\
\text { SF-36 }\end{array}$ & $\begin{array}{l}\text { QoL } \neq^{*} \text { iPEG vs CG } \\
\text { KDQOL-SFTM } \uparrow * \text { iPEG all the items } \\
\text { except for: pain, sexual function, } \\
\text { work status and CKD load } \\
\text { SF-36 }{ }^{*} \text { iPEG physical function; } \\
\text { limitations of physical function; } \\
\text { general health; energy/fatigue; } \\
\text { sleep; quality of social interac- } \\
\text { tion; list of symptoms/problems }\end{array}$ & $\begin{array}{l}\text { Customised iHD iPE significantly } \\
\text { improved the QoL of CKD patients } \\
\text { in a short period of time, and } \\
\text { therefore could be used as a } \\
\text { simple therapeutic focus with no } \\
\text { adverse effects }\end{array}$ \\
\hline
\end{tabular}

CG: control group; iPEG: physical exercise group; iPE: physical exercise; 9 : female; ${ }^{\pi}$ : male; HA: high adherence; MA: medium adherence; LA: low adherence; AW: aerobic; RE: strength CE: aerobic + strength; QoL: quality of life; SF-36: short form health test 36 items; QS: quality of sleep; MI: movement index; Fl: sleep fragmentation index; SFl: average sleep fragmentation index; TST: total sleep time; WASO: wake after sleep onset; SE: sleep efficiency; KDQOL-SFTM: kidney disease quality of life questionnaire; CKD: chronic kidney disease; HD: haemodialysis; HHD: intradialytic; LL: lower limbs.

exertion scale ${ }^{16,18,19}$. Furthermore, for the St iPE, intensity can also be optimised based on the repetition rate ${ }^{6}$ and for AW iPE optimum heart rate could be used following the Karvonen method ${ }^{6}$, or limit the increase to 20 beats between the basal situation and that of the $\mathrm{PEE}^{19}$. With regards to the exercise programmes performed, work was performed with AW resistance ${ }^{17-19}, \mathrm{St}^{15,20}$, and/or both simultaneously, in so-called combined exercise ${ }^{6,16}$. AW component iPE performed during HD consisted in stationary cycling on a supine-position cycloergometer ${ }^{6,16-19}$. St exercises with customised loads and with weight $\mathrm{t}^{56,15,20}$ or elastic resistance bands $s^{6,16,20}$, were performed using the upper limb muscles (UL), such as 
Table 5c. Summary of the biological markers assessment, results and conclusions of the studies included in the review that research the impact of physical exercise on patients with chronic kidney disease in haemodialysis.

\begin{tabular}{|c|c|c|c|c|}
\hline Autor & Población & Evaluación & Resultados & Conclusiones \\
\hline $\begin{array}{l}\text { Abreu et al.20 } \\
2017\end{array}$ & $\begin{array}{l}\mathrm{n}=44>18 \text { years } \\
\text { CG: } \mathrm{n}=19 \text { ( } 61.5 \% \text { \% aged } \\
42.5 \pm 13.5 \text { years and time of } \\
\text { dialysis }=70.1 \pm 49.9 \text { months). } \\
\text { iPEG: } \mathrm{n}=25 \text { ( } 54.5 \% \text { \% } \text {, aged } \\
45.7 \pm 15.2 \text { years and time of } \\
\text { dialysis }=71.2 \pm 45.5 \text { months) } \\
\text { iPEG adherence } 78.1 \%\end{array}$ & $\begin{array}{l}\text { GPx } \\
\text { hs-CRP } \\
\text { Nrf2 } \\
\text { NF-K } \beta \\
{[\text { Nitrite] }(\mu \mathrm{m})}\end{array}$ & $\begin{array}{l}\text { GPx }{ }^{*} \text { iPEG } \\
\text { hs-CRP } \downarrow \text { iPEG } \\
\text { Nrf2 } \uparrow * \text { iPEG } \\
\text { NF-k } \beta \approx \text { iPEG and } \approx \text { CG } \\
{[\text { Nitrite] }(\mu \mathrm{m}) \downarrow * \text { iPEG }}\end{array}$ & $\begin{array}{l}\text { Strength iPE over } 3 \text { months exercise } \\
\text { induced the expression of Nrf2 and } \\
\text { GPx, maintained nitrite levels }\end{array}$ \\
\hline $\begin{array}{l}\text { Groussard et } \\
\text { al. } .^{7} 2015\end{array}$ & $\begin{array}{l}n=2015 \sigma^{\pi} \text { and } 5 \text { ㅇ } \\
\text { Age } 20-85 \text { years } \\
\text { CG } n=10 \\
\text { iPEG } n=10 \\
\text { iPE adherence } 80 \%\end{array}$ & $\begin{array}{l}\text { Lipid profile } \\
\text { Cholesterol } \\
\text { HDL } \\
\text { LDL } \\
\text { TG } \\
\text { Pro/antioxidant activity } \\
\text { Ox-LDL } \\
\text { GSH/GSSG } \\
\text { GPx } \\
\text { SOD } \\
\text { F2IsoP }\end{array}$ & $\begin{array}{l}\text { Lipid profile } \\
\text { Cholesterol } \uparrow \text { CG } \downarrow_{\text {iPEG }} \\
\mathrm{HDL} \approx \mathrm{CG} \text { and iPEG } \\
\mathrm{LDL} \approx \mathrm{CG} \downarrow_{\text {iPEG }} \\
\mathrm{TG} \approx \mathrm{CG} \downarrow \downarrow^{*} \text { iPEG } \\
\text { Pro/antioxidant activity } \\
\mathrm{Ox}-\mathrm{LDL} \approx \mathrm{GG} \text { and iPEG } \\
\mathrm{GSH} / \mathrm{GSSG} \approx \mathrm{CG} \text { and iPEG } \\
\mathrm{GPx} \approx \mathrm{CG} \text { and iPEG } \\
\mathrm{SOD} \approx \mathrm{CG} \text { and iPEG } \\
\mathrm{F} 2 \mathrm{soP} \uparrow^{*} \mathrm{CG} \approx \mathrm{iPEG}\end{array}$ & $\begin{array}{l}\text { An iHD AW cycling training program- } \\
\text { me has beneficial effects on the lipid } \\
\text { profile (lowering plasma TG) and avoi- } \\
\text { ding the increase of basal oxidation } \\
\text { (without worsening the F2IsoP, which } \\
\text { is the most reliable and specific marker } \\
\text { of lipid peroxidation), considering } \\
\text { the relatively short duration of just } 3 \\
\text { months with } 36 \text { sessions on patients } \\
\text { with CKD in HD. }\end{array}$ \\
\hline $\begin{array}{l}\text { Liao et al. }{ }^{18} \\
2016\end{array}$ & $\begin{array}{l}n=4023 \text { and } 170^{x} \\
\text { Age } 62 \pm 8 \text { years } \\
\text { CG } n=20 \\
\text { iPEG } n=20 \\
\text { iPE adherence not specified }\end{array}$ & $\begin{array}{l}\text { Blood pressure } \\
\text { Systolic Diastolic } \\
\text { Heart Rate } \\
\text { Biochemistry } \\
\text { iPTH Ca2+ tHcy hs-CRP IL-6 } \\
\text { Albumin Creatine ALT Cho- } \\
\text { lesterol } \\
\text { Hematocrit Kt/V nPCR BMI } \\
\text { weight } \\
\text { Endothelial Progenitor Cells } \\
\text { CD133+CD34+ KDR+ }\end{array}$ & 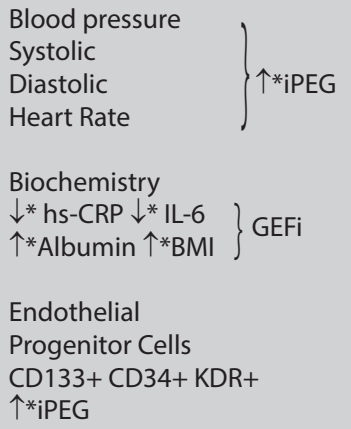 & $\begin{array}{l}\text { iPE of iHD AW cycling at a moderate } \\
\text { intensity improves: the nutritional state } \\
\text { and cardiovascular resistance of CKD } \\
\text { patients in HD, reduces the cardiovas- } \\
\text { cular risk, inflammatory responses, } \\
\text { which } \\
\text { could contribute to these beneficial } \\
\text { effects of exercise. }\end{array}$ \\
\hline
\end{tabular}

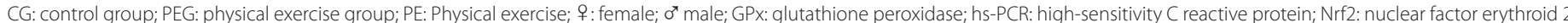

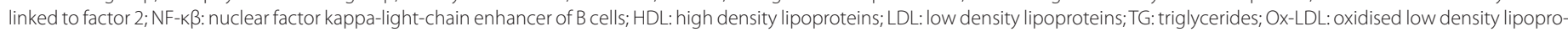

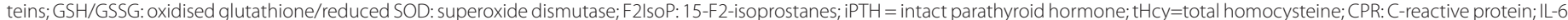

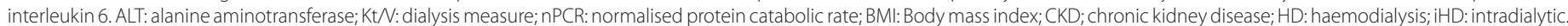

the biceps, deltoids, triceps $s^{6,15,16}$ and the lower limbs (LL), working the quadriceps, hamstrings, abdomen and adductor muscles $6,15,16,20$. In arm St work of the arteriovenous fistula (AVF), the patients received highly conservative recommendations ${ }^{7}$, constituting an obstacle to performing St iPE ${ }^{8}$. However, there is no clinical evidence to suggest that limitations should be imposed to St work once the AVF has been correctly healed and when St work progression is gradual ${ }^{25}$. St iHD iPE is performed on the arm without vein access, whilst the exercises on the arm with AVF were performed just before the HD ${ }^{15,16}$. It is important to highlight that no adverse events occurred linked to the AVF with St routines $6,15,16$.

\section{Effects on function and physical capacity}

Patients with CKD in HD have considerably reduced tolerance to exercise, in functional capacity, in AW and in St. They also suffer from greater muscle mass loss, which along with anaemia, constitute key factors in the reduction of functional and physical capacity ${ }^{26}$. However, practising iPE can help compensate this physical deterioration. In this respect, performing AW iPE in monotherapy ${ }^{17-19}$, allows for significant improvement in AW assessment tests. 6 min walking test ${ }^{17-19}$; timed up and go test ${ }^{19}$; sit to stand test ${ }^{19} ; 22$ steps; sit-to-stand test ${ }^{19}$ and even a St test using a manual dynamometer, the grip strength test ${ }^{19}$. In the study by Groussard et al. ${ }^{17}$, which significantly improved the distance covered ( 6 min walking test) in the iPE group by $23.4 \%$, there was no effect on $\mathrm{VO}_{2}$ maximum. This is perhaps because the changes caused by training at $\mathrm{VO}_{2}$ maximum are positively linked to the duration of the iPE. More important changes have been described in $\mathrm{VO}_{2}$ maximum, in patients that performed combined iPE (AW + St) for 6 or more months extra-dialytic ${ }^{27}$. Gains in St after exclusive St training were significant in 
the $U L$ and the $L L^{6,15}$. However, the patients with better adherence to the iPE programme obtained greater increases (120\%) than patients with lower adherence (40-50\%) ${ }^{6}$. The same occurred with significant improvements in AW resistance, with gains of 55\% for patients with high adherence and $45 \%$ for average adherence 6 . This would indicate that adherence to iPE plays a key role in improving physical function and capacity of CKD in HD.

Studies that performed combined $\mathrm{PE}^{6,16}$ revealed significant improvements in St and AW capacity ${ }^{6}$ and in daily physical activity ${ }^{16}$. The study by Cho et al. ${ }^{16}$, revealed significant increases in equivalent metabolic rate (EMR) in the AW iPE and combined IPE between the basal situation and following 36 sessions. Significant increases were also demonstrated between the combined iPE group and the control group at the end of the study. Therefore, an increase of the EMRs is directly linked to the significant increase of active episodes of time spent performing moderate combined $\mathrm{iPE}^{16}$. These health-related outcomes linked to physical function and daily physical activity suggest that combined $\mathrm{HD}$ ¡PE is the most suitable type during HD to contribute to delaying the progression of $\mathrm{CKD}^{5}$. Logically, following an iHD iPE programme (AW, St or combined) reduces sedentary episodes ${ }^{16}$.

\section{Effects on health-related quality of life}

Determining health-related quality of life (HRQOL) that establishes multidimensional health outcomes ${ }^{28}$, may contribute to establishing, perfecting and assessing iHD iPE programmes.

The most used tool by the studies analysed in this work was the

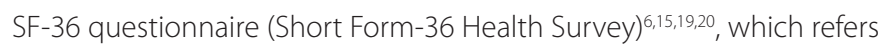
to what the patients think about their own health, how they feel and if they are able to perform routine activities ${ }^{29}$. Generally speaking, iHD iPE programmes contributed to improving the HRQOL assessed using the SF-36, and results were significant in the physical ${ }^{6,15,19,20}$, mental ${ }^{6,20}$, social ${ }^{15,19}$, emotional ${ }^{15}$, general health ${ }^{19,20}$ and QS ${ }^{19}$ sub-scales. Wu et al. ${ }^{19}$ assessed HRQOL using the KDQOL-SFTM (Kidney Disease Quality of Life Short Form), which includes the SF-12 as the generic core of HRQOL plus the load of kidney disease ${ }^{28}$, with HRQOL significantly improving in practically all the generic and specific dimensions of the KDQOL-SFTM.

$\mathrm{HRQOL}$ in CKD patients is also related to alterations of QS and/or uraemic restless leg syndrome ${ }^{30}$. Cho et al. ${ }^{16}$ described improvements in QS after 12 weeks of iHD iPE, demonstrating in particular a significant decrease of the movement index for the iPE group (AW, St and combined) and also a significant reduction in the sleep fragmentation index compared to the control group. These results were similar to those reported previously by Afshar et al. ${ }^{31}$. Furthermore, an increase in opioid levels ( $\beta$-endorphins) from performing iPE, appears to be one of the mechanisms that attenuates restless leg syndrome ${ }^{32}$ and would lead to improved QS. In addition, the improvements that iPE has on emotional factors $^{15}$, depression ${ }^{15}$, increased energy consumption assessed in the EMRs $^{16}$ and in physical capacities ${ }^{6,15-19}$, could lead to improvements in QS, which would stimulate good HRQOL in CKD patients.

\section{Effects on biological markers}

The possibility of using biomarkers and tools to monitor iHD iPE programmes could allow us to assess the effectiveness of iPE and the progression of the CKD in real time ${ }^{5}$. Some biomarkers have already been used to control iHD iPE studies ${ }^{17,18,20}$.

OS and inflammation play a key role in the development and progression of CKD, and in addition, its complications - such as endothelial dysfunction and bone mineral disease - are critical factors that contribute to the morbimortality of patients in $\mathrm{HD}^{33}$. Moreover, physical inactivity is an important factor that contributes to chronic inflammation and to the alteration of the pro/antioxidant balance ${ }^{25}$. OS is caused by a deficiency in endogenous antioxidant capacity and the increased production of reactive oxygen species (ROS) activating various transcription factors, including the nuclear factor $\mathrm{kB}(\mathrm{NF}-\mathrm{kB})$, which regulates the expression of genes responsible for activating the synthesis of inflammatory cytokines like the interleukin-6 (IL-6), interleukin-8 (IL-8), and the monocyte chemotactic-1 (MCP-1) 34 . However, Nrf2 is recognised as a transcription factor responsible for suppressing the pro-inflammatory signalling channels and activating antioxidant mechanisms mediated by NF-KB ${ }^{35}$. In the study by Abreu et al. ${ }^{20}$, after 12 weeks of St iPE, the expression of $\mathrm{Nrf2}$ and of glutathione peroxidase (GPX) were significantly induced. Therefore, the increase of the Nrf2 expression could a therapeutic strategy to reduce $O S$ and inflammation in patients with CKD associated NF-KB. Although this study ${ }^{20}$ is the only one to assess Nrf2 in humans during iPE in HD, there is evidence in murine models with CKD that prove that iPE can increase the expression of the Nrf2 gene ${ }^{35,36}$. The GPx neutralises OS and reduces the ROS ${ }^{37}$, the significant increase of this GPx enzyme would stimulate the defence of the organism in CKD patients against the damaging effect of the OS and the ROS. The inflammatory states also revealed a tendency to reduce, which is reflected in the decrease of high-sensitivity C reactive protein (hs-CRP), which is a risk factor associated with cardiovascular disease in CKD patients in $\mathrm{HD}^{31}$. Together, these findings could position 12-week St iHD iPE as a modulating therapy of IS and of inflammation in patients with CKD.

Triglyceridemia is the most common blood lipids anomaly in patients with CKD and is considered a cardiovascular disease risk factor ${ }^{5}$ Groussard et al. ${ }^{17}$ observed a significant reduction in the triglyceride plasma concentration (-23\%), indicating an improvement in the lipid profile, after 36 AW iPE sessions. Furthermore, it prevents the increase of OS as it keeps isoprostane F2 $\alpha$ (F2 $\alpha$-IsoP) levels under control, which is the most reliable and specific marker of lipid peroxidation in the IPE group. In turn, in the control group F2 $\alpha$-IsoP uncreased significantly. Therefore, AW iPE comprising stationary cycling iHD, could represent a useful strategy against hypertriglyceridemia and an increase in OS.

Endothelial progenitor cells (EPC) mobilised from the bone marrow, work as an endogenous agent in repairing the vascular endothelial system, contributing to angiogenesis and combating atherosclerosis. During CKD, EPC function reduces and deteriorates, which contributes to an increased risk of cardiovascular disease in patients with $\mathrm{HD}^{38}$. $\mathrm{iHD}$ 
stationary cycling AW iPE ${ }^{18}$ significantly increased the number of EPC, monitored by CD133, CD34 and KDR in patients with CKD in HD. Furthermore, inflammation of endothelial cells causes EPC dysfunction. Therefore, the anti-inflammatory effect of iPE can contribute to increasing the number and improvement of EPC function. The anti-inflammatory effect of AW iPE was proven with the significant reductions of IL-6 and hs-CRP. Furthermore, these authors 18 revealed a high correlation $(r=0.721 p<0.001)$ between the EPC and the significant improvement of AW capacity in the 6 min walking test.

Therefore, these results, assessed using biomarkers, reveal that moderate intensity AW and/or St HD iPE performed over 3 months, is able to reduce the risk of mortality due to the multiple co-morbidities of CKD patients, especially cardiovascular risks, by reducing OS (stimulating NrF2 and GPx; modulation of F $2 \alpha$-IsoP), inflammation (reduction of IL- 6 and hs-CRP), regulation of the lipid profile (reduction of plasma triglycerides) and stimulation of the EPC.

\section{Limitations and strengths}

The main limitations are linked to the low number of studies researched on this issue and with the relatively small number of participants. We should highlight that the two studies were not randomised and one of them used a crossover design. They were performed on demographics with different levels of physical activity and research protocols, which increases heterogeneity between the studies. However, all the subjects were at the same stage of the illness IV, with 3 or more months of maintenance HD. Furthermore, a strength of this systematic review would be the quality control via PRISMA and Mc Master.

\section{Conclusion}

Performing iHD iPE with AW, St and combined work programmes, stimulates health outcomes related to physical capacity and function; HRQOL and biological markers. Performing iPE leads to increased aerobic resistance, $U L$ and $L L$ muscle strength, reduces sedentary behaviour, and has a direct beneficial effect on the HRQOL of CKD patients, giving them emotional, social and psychological improvements. Furthermore, iHD iPE is able to control the OS stimulating NrF2 and GPx and the modulation of $F 2 \alpha$-IsoP, inflammation caused by the reduction of IL- 6 and hs-CRP, the regulation of the lipid profile and a reduction of plasma triglycerides and the stimulation of the EPC. Along with these outcomes, they allow for reduced mortality risks associated with the multiple co-morbidities of CKD patients, particularly cardiovascular.

\section{Acknowledgements}

The authors acknowledge the Cellular, Histology and Pharmacological Department, Health Sciences Faculty, University of Valladolid in the Soria Campus and the Neurobiology Research Group, Medicine Faculty, University of Valladolid.

\section{Conflict of interest}

The authors claim to have no conflict of interest whatsoever.

\section{Bibliography}

1. Levey AS, Coresh J. Chronic kidney disease. Lancet. 2012;379:165-80.

2. Fernández Lara MJ, Ibarra Cornejo JL, Aguas Alveal EV, González Tapia CE, Reffers Q, Galvarino D. Beneficios del ejercicio físico en pacientes con enfermedad renal crónica en hemodiálisis. Enferm Nefrol. 2018;21:167-81.

3. Stack AG, Molony DA, Rives T, Tyson J, Murthy BV. Association of physical activity with mortality in the US dialysis population. Am J Kidney Dis. 2005;45:690-701.

4. Howden EJ, Coombes JS, Strand H, Douglas B, Campbell KL, Isbel NM. Exercise training in CKD: efficacy, adherence, and safety. Am J Kidney Dis. 2015;65:583-91.

5. Webster AC, Nagler EV, Morton RL, Masson P. Chronic kidney disease. Lancet. 2017;389: 1238-52.

6. Anding K, Bär T, Trojniak-Hennig J, Kuchinke S, Krause R, Rost JM, et al. A structured exercise programme during haemodialysis for patients with chronic kidney disease: clinical benefit and long-term adherence. BMJ Open. 2015;5:e008709.

7. Wilund KR, Jeong $J H$, Greenwood SA, editors. Addressing myths about exercise in hemodialysis patients. Seminars in dialysis; 2019: Wiley Online Library.

8. Cheema B, Abas H, Smith B, O'Sullivan A, Chan M, Patwardhan A, et al. Progressive exercise for anabolism in kidney disease (PEAK): a randomized, controlled trial of resistance training during hemodialysis. J Am Soc Nephrol. 2007;18:1594-601.

9. Sheng K, Zhang P, Chen L, Cheng J, Wu C, Chen J. Intradialytic exercise in hemodialysis patients: a systematic review and meta-analysis. Am J Nephrol. 2014;40:478-90.

10. Parsons TL, Toffelmire EB, King-VanVlack CE. Exercise training during hemodialysis improves dialysis efficacy and physical performance. Arch Phys Med Rehabil. 2006;87:680-7.

11. Oguchi H, Tsujita M, Yazawa M, Kawaguchi T, Hoshino J, Kohzuki M, et al. The efficacy of exercise training in kidney transplant recipients: a meta-analysis and systematic review. Clin Exp Nephrol. 2019;23:275-84.

12. Gomes Neto M, De Lacerda FFR, Lopes AA, Martinez BP, Saquetto MB. Intradialytic exercise training modalities on physical functioning and health-related quality of life in patients undergoing maintenance hemodialysis: systematic review and meta-analysis. Clin Rehabil. 2018;32:1189-202.

13. Liberati A, Altman DG, Tetzlaff J, Mulrow C, Gøtzsche PC, loannidis JP, et al. The PRISMA statement for reporting systematic reviews and meta-analyses of studies that evaluate health care interventions: explanation and elaboration. Ann Intern Med. 2009;151:W65-W94.

14. Law M, Stewart C, Pollock N, Letts L, Bosch J, Westmorland M. McMaster critical review form-Quantitative studies. Hamilton, Ontario: McMaster University Occupational Therapy Evidence-Based Practice Research Group. 1998

15. Chan D, Green S, Fiatarone Singh M, Barnard R, Cheema BS. Development, feasibility, and efficacy of a customized exercise device to deliver intradialytic resistance training in patients with end stage renal disease: Non-randomized controlled crossover trial. Hemodial Int. 2016;20:650-60.

16. Cho J-H, Lee J-Y, Lee S, Park H, Choi S-W, Kim JC. Effect of intradialytic exercise on daily physical activity and sleep quality in maintenance hemodialysis patients. Int Urol Nephrol. 2018;50:745-54.

17. Groussard C, Rouchon-Isnard M, Coutard C, Romain F, Malardé L, Lemoine-Morel S, et al. Beneficial effects of an intradialytic cycling training program in patients with end-stage kidney disease. Appl Physio/ Nutr Metab. 2015;40:550-6.

18. Liao M-T, Liu W-C, Lin F-H, Huang C-F, Chen S-Y, Liu C-C, et al. Intradialytic aerobic cycling exercise alleviates inflammation and improves endothelial progenitor cell count and bone density in hemodialysis patients. Medicine (Baltimore). 2016;95:e4134

19. Wu Y, He Q, Yin X, He Q, Cao S, Ying G. Effect of individualized exercise during maintenance haemodialysis on exercise capacity and health-related quality of life in patients with uraemia. J Int Med Res. 2014;42:718-27.

20. Abreu C, Cardozo L, Stockler-Pinto M, Esgalhado M, Barboza J, Frauches R, et al. Does resistance exercise performed during dialysis modulate Nrf2 and NF-KB in patients with chronic kidney disease? Life Sci. 2017;188:192-7.

21. Dungey M, Bishop NC, Young HM, Burton JO, Smith AC. The impact of exercising during haemodialysis on blood pressure, markers of cardiac injury and systemic inflammationpreliminary results of a pilot study. Kidney Blood Press Res. 2015;40:593-604.

22. Rodriguez HJ, Domenici R, Diroll A, Goykhman I. Assessment of dry weight by monitoring changes in blood volume during hemodialysis using Crit-Line. Kidney Int. 2005;68:854-61.

23. Moore GE, Painter PL, Brinker KR, Stray-Gundersen J, Mitchell JH. Cardiovascular response to submaximal stationary cycling during hemodialysis. Am J Kidney Dis. 1998;31:631-7.

24. Jeong JH, Biruete A, Fernhall B, Wilund KR. Effects of acute intradialytic exercise on cardiovascular responses in hemodialysis patients. Hemodial Int. 2018;22:524-33. 
25. Smart NA, Williams AD, Levinger I, Selig S, Howden E, Coombes JS, et al. Exercise \& Sports Science Australia (ESSA) position statement on exercise and chronic kidney disease. J Sci Med Sport. 2013;16:406-11.

26. Hernández Sánchez S, García López D, Santos Lozano A, González-Calvo G, Brazález Tejerina M, Garatachea Vallejo N. Valoración física, condición física y calidad de vida en pacientes con diferentes tratamientos renales sustitutivos. Enferm Nefrol. 2015;1 8:81-8.

27. Smart N, Steele M. Exercise training in haemodialysis patients: a systematic review and meta-analysis. Nephrology (Carlton). 2011;16:626-32.

28. Capote Leyva E, Argudín Selier R, Mora González S, Capote Pereira L, Leonard Rupalé I, Moret Hernández Y. Evaluación de la calidad de vida relacionada con salud en pacientes en hemodiálisis periódica utilizando el KDQOL-SFTM. MediSur. 2015;13:508-16.

29. Rebollo-Rubio A, Morales-Asencio JM, Pons-Raventos ME, Mansilla-Francisco JJ. Revisión de estudios sobre calidad de vida relacionada con la salud en la enfermedad renal crónica avanzada en España. Nefrología (Madr). 2015;35:92-109.

30. Giannaki CD, Sakkas GK, Karatzaferi C, Hadjigeorgiou GM, Lavdas E, Liakopoulos V, et al. Evidence of increased muscle atrophy and impaired quality of life parameters in patients with uremic restless legs syndrome. PLoS One. 2011;6:e25180.

31. Afshar R, Emany A, Saremi A, Shavandi N, Sanavi S. Effects of intradialytic aerobic training on sleep quality in hemodialysis patients. Iran J Kidney Dis. 2011;5:119-23.
32. Von Spiczak S, Whone AL, Hammers A, Asselin M-C, Turkheimer F, Tings T, et al. The role of opioids in restless legs syndrome: an [11C] diprenorphine PET study. Brain. 2005;128:906-17.

33. Carrero JJ, Stenvinkel P, Cuppari L, Ikizler TA, Kalantar-Zadeh K, Kaysen G, et al. Etiology of the protein-energy wasting syndrome in chronic kidney disease: a consensus statement from the International Society of Renal Nutrition and Metabolism (ISRNM). J Renal Nutr. 2013;23:77-90

34. Sanz AB, Sanchez-Niño MD, Ramos AM, Moreno JA, Santamaria B, Ruiz-Ortega M, et al. NF-KB in renal inflammation. J Am Soc Nephrol. 2010;21:1254-62.

35. Kim H-J, Vaziri ND. Contribution of impaired Nrf2-Keap1 pathway to oxidative stress and inflammation in chronic renal failure. Am J Physiol Renal Physiol. 2010;298:F662-71.

36. Done AJ, Gage MJ, Nieto NC, TraustadóttirT. Exercise-induced Nrf2-signaling is impaired in aging. Free Radic Biol Med. 2016;96:130-8.

37. Lubos E, Loscalzo J, Handy DE. Glutathione peroxidase-1in health and disease: from molecular mechanisms to therapeutic opportunities. Antiox Redox Signal. 2011; 15:1957-97.

38. Choi J-H, Kim KL, Huh W, Kim B, Byun J, Suh W, et al. Decreased number and impaired angiogenic function of endothelial progenitor cells in patients with chronic renal failure. Arterioscler Thromb Vasc Biol. 2004;24:1246-52. 